\title{
Reduced Sensitivity to Glucocorticoid Feedback and Reduced Glucocorticoid Receptor mRNA Expression in the Luteal Phase of the Menstrual Cycle
}

\author{
Margaret Altemus, M.D., Laura Redwine, Ph.D., Yung-Mei Leong, Takeo Yoshikawa, Ph.D.,
} Rachel Yehuda, Ph.D., Savilla Detera-Wadleigh, Ph.D., and Dennis L. Murphy, M.D.

We examined the effects of the menstrual cycle on hypothalamic-pituitary adrenal axis regulation in healthy women with no history of psychiatric illness by measuring plasma cortisol responses to a low-dose $(0.25 \mathrm{mg})$ of dexamethasone $(\mathrm{N}=23)$ and by measuring glucocorticoid receptor (type II) $m R N A$ expression in lymphocytes using Northern blotting $(\mathrm{N}=19)$. Both measures were performed in the early follicular and mid-luteal phases of the menstrual cycle. Dexamethasone suppression of plasma cortisol was greater in the follicular phase of the menstrual cycle compared to the mid-luteal phase $(\mathrm{p}<.01)$. In addition, type II glucocorticoid receptor $m R N A$ expression in lymphocytes was $78 \%$ higher in the follicular phase compared to the mid-luteal phase $(\mathrm{p}<.02)$. These results indicate that glucocorticoid feedback regulation of the hypothalamic-pituitary-adrenal axis is reduced in the midluteal phase of the menstrual cycle. Reduced feedback regulation of central stress response systems may play a role in generation of common premenstrual symptoms of irritability and dysphoria. [Neuropsychopharmacology 17:100-109, 1997] Published by Elsevier Science Inc.
KEY WORDS: Glucocorticoid receptor; Menstrual cycle; Lymphocyte; Dexamethasone; Cortisol; $m R N A$

Glucocorticoids are important in feedback regulation of several stress response systems, including the hypothalamic-pituitary-adrenal (HPA) axis and noradrenergic systems (Brown and Fisher 1986; Chrousos and Gold 1992). Alterations in glucocorticoid feedback regulation of the HPA axis have been demonstrated diurnally

From the Department of Psychiatry, Cornell University Medical College (MA); Department of Pharmacology, Georgetown University Medical School (LR); Laboratory of Clinical Science (Y-ML, DLM), and Clinical Neurogenetics Branch, Division of Intramural Research Programs, NIMH (TY, SD-W); Department of Psychiatry, Mt. Sinai School of Medicine (RY).

Address correspondence to: Margaret Altemus, M.D., Box 244, Cornell University Medical College, 1300 York Ave., New York, NY 10021.

Received August 20, 1996; revised December 20, 1996; accepted February 13, 1997.
(Spencer et al. 1993; Bradbury et al. 1994), with age (Sapolsky et al. 1986; Rothuizen et al. 1993), in inflammatory disease (Crofford et al. 1994; Michelson et al. 1994) and in association with several neuropsychiatric disorders (DeLeon et al. 1988; Young et al. 1993; Yehuda et al. 1995). One clearly documented mechanism of feedback regulation of the HPA axis is downregulation of glucocorticoid receptor synthesis, content and binding in a variety of tissues in response to increases in circulating glucocorticoid levels (Schlechte et al. 1982; Kalinyak et al. 1987; Dong et al. 1988; Herman et al. 1989a; Bellingham et al. 1992).

In addition, a number of studies in female rats indicate that glucocorticoid feedback regulation of the HPA axis is also modulated by circulating levels of estrogen. Ovariectomized rats have reduced $\mathrm{ACTH}$ and corticosterone responses to stress (Kitay 1963; Viau and Meaney 1991; Burgess and Handa 1992), increased glucocorti- 
coid receptor binding (Turner and Weaver 1985) and increased expression of mRNA for the glucocorticoid receptor in the hippocampus (Burgess and Handa 1994; Carey et al. 1995), hypothalamus (Swanson and Simmons 1989; Peiffer et al. 1991; Burgess and Handa 1993), pituitary (Peiffer and Barden 1987) and thymus (Peiffer et al. 1994), and enhanced suppression in vivo of adrenocorticotropin and cortisol in response to administration of a type II glucocorticoid receptor agonist (Burgess and Handa 1992). These changes are reversed by administration of estrogen, but results of progesterone replacement are more variable (Kitay 1963; Peiffer and Barden 1987; Peiffer et al. 1991; Viau and Meaney 1991; Burgess and Handa 1992; Peiffer et al. 1994; Carey et al. 1995). Moreover, in rats, naturalistic comparisons of proestrus and estrus have found during estrus, the phase with lower estrogen and progesterone secretion, relatively reduced HPA axis reactivity (Pollard et al. 1975; Viau and Meaney 1991; Carey et al. 1995), increased glucocorticoid receptor mRNA expression (Peiffer et al. 1994), reduced hypothalamic corticotropin releasing hormone content (Haas and George 1988) and reduced corticotropin releasing hormone mRNA expression (Bohler et al. 1990; Viau and Meaney 1991; Peiffer et al. 1994).

Although numerous studies in humans have documented stability of baseline cortisol levels across the menstrual cycle (Aubert et al. 1971; Schoneshofer and Wagner 1977; Parker et al. 1981; Rubinow et al. 1988; Rabin et al. 1990; Heitkemper et al. 1991), there has been little examination of possible changes in tissue sensitivity to glucocorticoids during the menstrual cycle.

We performed two studies in humans to begin to investigate possible gonadal steroid induced changes in glucocortocoid feedback sensitivity. Both studies were performed in the early follicular and mid-luteal phases of the menstrual cycle to maximize differences in serum levels of estradiol and progesterone: 1) Cortisol suppression was measured in response to a $0.25 \mathrm{mg}$ dose of dexamethasone. This low dose was chosen to enhance the sensitivity of the test, since previous studies had shown that the standard $1 \mathrm{mg}$ dose of dexamethasone caused near maximal cortisol suppression in both phases of the cycle (Parker et al. 1983; Roy-Byrne et al. 1986); and 2) Type II glucocorticoid receptor mRNA expression in peripheral blood lymphocytes was measured using northern blotting. We measured type II, rather than type I receptor mRNA expression because type II receptors are though to play a more important role in regulation of acute stress responses (Reul and deKloet 1985; DeKloet and Reul 1987) and are more sensitive to activation by dexamethasone (Spencer et al. 1990; Miller et al. 1992). In addition, type II receptor mRNA is much more abundant than type I receptor mRNA in lymphocytes. In two prior studies quantitative sensitivity of Northern blotting of type II glucocorticoid receptor mRNA was adequate to detect changes in mRNA expression in response to glucocorticoid challenges (Denton et al. 1993; Knuttson et al. 1995).

\section{METHODS}

\section{Subjects}

Subjects were 23 healthy women with no history of psychiatric illness, substance abuse, or premenstrual syndrome as assessed by clinical interview and a modified version of a structured psychiatric diagnostic interview (SCID) (Spitzer et al. 1990). Family psychiatric history information was not collected from these subjects. Subjects had regular menstrual cycles (25-35 days) by history. Mean \pm SD age was $29.4 \pm 6.5$ years (range 20-39). 18 were Caucasian, 3 Asian, and 2 African American. All subjects had normal physical examinations and normal screening laboratory tests including complete blood count, thyroid function tests, urinalysis, urine pregnancy test, and urine toxicology screen. No subjects had been taking any medication in the preceding 3 months. No subjects regularly consumed more than two drinks of alcohol per week. Subjects were instructed not to drink any alcohol during the 24 hours preceding any blood collection.

All subjects gave prior informed consent, and the experimental protocol was approved by the NIMH Intramural Institutional Review Board.

\section{Timing of Procedures}

Both the low dose dexamethasone suppression test and blood drawing for determination of glucocorticoid receptor mRNA expression were performed in both the early follicular (3-6 days after onset of menses) and midluteal (7-10 days after luteinizing hormone surge) phases of the menstrual cycle. Each woman determined the time of her luteinizing hormone surge by using a home urine test kit (Clearplan Easy, Unipath Limited, Bedford, UK). Although the same group of subjects participated in both test procedures, the two procedures were often performed in separate menstrual cycles. Seventeen of 23 subjects completed dexamethasone suppression testing within one menstrual cycle and 17 of 19 subjects completed blood draws for glucocorticoid receptor mRNA measures within one menstrual cycle. The other subjects required up to 3 cycles to complete testing due to scheduling difficulties and failure to detect a luteinizing hormone surge needed for scheduling of the luteal test.

\section{Low-Dose Dexamethasone Suppression Test}

Seventeen of the 23 subjects were tested first in the follicular phase of the cycle and 6 subjects were tested first in the luteal phase. For each dexamethasone suppression test, subjects had blood drawn at 8 A.M. for mea- 
surement of baseline cortisol. At 11 P.M. that night they took $0.25 \mathrm{mg}$ dexamethasone, and blood was drawn to measure serum cortisol and dexamethasone levels at 8 A.M. and 4 P.M. the following day.

Cortisol was measured using a fluorometric assay at the NIH Clinical Center Laboratory. Detection limit of the cortisol assay was $27 \mathrm{nmol} / \mathrm{L}$. Dexamethasone levels were measured by radioimmunoassay as previously described (Yehuda et al. 1993). The intra assay coefficient of variation was $10.2 \%$ and the interassay coefficient of variation was $11 \%$.

\section{Lymphocyte Type II Glucocorticoid Receptor mRNA Expression}

Twenty milliliters of peripheral venous blood were drawn into chilled tubes containing EDTA at 8 A.M. in both phases of the cycle and kept on ice.

Mononuclear cells were isolated within one hour of collection by layering whole blood over lymphocyte separation medium (Organon Tecknika Corp., Durham, $\mathrm{NC})$. Lymphocytes were collected from the interface after centriguation at $200 \mathrm{~g}$ at $4^{\circ} \mathrm{C}$ for 20 minutes, washed twice with phosphate buffered saline, and frozen at $-30^{\circ} \mathrm{C}$ until extraction of RNA. Lymphocyte total RNA was extracted using the acid guanidine thiocyanate-phenolchloroform extraction method (Chomczynski and Sacchi 1987) and then redissolved in $7 \mu 1$ DEPC-treated water. The quantity and quality of RNA were determined by optical density (OD) at 260 and $280 \mathrm{~nm}$. For each sample the $\mathrm{OD}_{260} / \mathrm{OD}_{280}$ ratio was over 1.5. Extracted RNA was resolved by electrophoresis on formaldehyde gels, blotted onto a Nytran nylon membrane (Schleider and Schnell, Keene, $\mathrm{NH}$ ) and fixed with UV irradiation (Stratalinker, Stratagene, La Jolla, CA). A cDNA probe for human type II glucocorticoid receptor was made by PCR amplification using the plasmid clone pRShGRa (Giguere et al. 1986). The upstream primer spanned nucleotides 657-677 and the downstream primer spanned nucleotides 1687-1710 (Hollenberg et al. 1985). The cDNA probe was labelled with ${ }^{32} \mathrm{P}$ dCTP using a random primer DNA labeling kit (Boehringer Mannheim, Indianapolis, IN). Blots were incubated for 2 hours at $42^{\circ} \mathrm{C}$ with Hybrizol I (Oncor, Gaithersburg, MD), and then hybridized with Hybrizol I and $2 \%$ SDS containing $2 \times 106 \mathrm{spm} / \mathrm{ml}$ labeled probe for 24 hours at $42^{\circ} \mathrm{C}$. The blots were washed four times with increasing stringency. The final wash was $0.1 \times \mathrm{SSC}$ and $0.1 \times \mathrm{SDS}$ at $55^{\circ} \mathrm{C}$. Hybridization of the labeled human glucocorticoid receptor cDNA probe applied to the membrane was measured directly from the nylon membrane using a Betagen Betascope Blot Analyser (Natick, MA). Membranes were stripped and rehybridized with rat glyceraldehyde-3-phosphate (GAPDH) probe (nucleotide position 87-1077) (Fort et al. 1985) to correct for variability in RNA loading. The ratio of glucocorticoid receptor
mRNA to GAPDH mRNA was determined for each sample. Follicular and luteal samples from each subject were run together on the same gel. A stored supply of total mRNA from a Hela cell line was used as an inter assay control on each gel. There was little variation in Hela GR/GAPDH reading from different gels $(<10 \%)$.

\section{Estradiol and Progesterone Levels}

Estradiol and progesterone were measured by radioimmunoassay in the NIH Clinical Center Laboratory. Detection limit of the estradiol assay was $36 \mathrm{pmol} / \mathrm{L}$. The intra assay coefficient of variation was $5.2 \%$ and the interassay coefficient of variation was $9.8 \%$ at $100 \mathrm{pg} / \mathrm{ml}$. The detection limit of the progesterone assay was 1.3 $\mathrm{nmol} / \mathrm{L}$ and the intra assay coefficient of variation was $6.4 \%$ and the interassay coefficient of variation was $8.7 \%$ at $1.3 \mathrm{ng} / \mathrm{ml}$.

\section{Statistics}

Differences in basal hormone levels and glucocorticoid receptor mRNA measures between the follicular and luteal phases of the menstrual cycle were evaluated using paired t-tests. Changes in cortisol and dexamethasone levels during the course of each dexamethasone suppression test in the two phases of the cycle were compared using a repeated measures ANOVA with two within subjects factors (blood sampling time and cycle phase). Significant differences in the ANOVAs were evaluated with post-hoc contrasts. Relationships among variables were assessed using Pearson's correlation coefficient. Post-dexamethasone changes in cortisol from the 8 A.M. baseline before dexamethasone administration were calculated for use in correlational analyses. All data are presented as means \pm SEM.

\section{RESULTS}

\section{Low-Dose Dexamethasone Suppression Test}

Results are presented in Table 1.

Estradiol and progesterone levels were lower in the follicular compared to the luteal phase of the menstrual cycle, $(t=7.3, p<.001)$ and $(t=11.8, p<.0001)$, respectively.

Basal cortisol levels did not differ significantly in the follicular and luteal phases of the cycle $(t=1.7, p=.10)$. As expected, there was a significant main effect of dexamethasone on plasma cortisol levels $(\mathrm{F}(2,44)=75.1$, $p<.0001)$. There was no main effect of menstrual cycle phase on cortisol levels $(\mathrm{F}(1,22)=2.0, p=.18)$, but there was a significant interaction between cycle phase and change in cortisol during the dexamethasone suppression test $(F(2,44) \pm 6.7, p<.01)$. Post hoc contrasts showed that post dexamethasone cortisol levels were 
significantly lower at 8 A.M. in the follicular compared to the luteal phase of the cycle $(p<.01)$, while 4 P.M. post-dexamethasone cortisol levels did not differ significantly in the follicular compared to the luteal phase $(p=$ .16). When post-dexamethasone cortisol levels were subtracted from the 8 A.M. baseline cortisol level to control for individual differences in basal cortisol level, change in cortisol compared to baseline cortisol level in follicular vs. luteal phases of the cycle was significant at both 8 A.M. $(t=3.7, p<.01)$ and 4 P.M. $(t=2.3, p<.04)$ (Figure 1).

As expected there was a significant effect of sampling time on plasma dexamethasone levels $(\mathrm{F}(1,21)=$ $245.5, p<.0001)$. Dexamethasone levels were higher at 8 A.M. than at 4 P.M. There was no effect of cycle phase on dexamethasone level $(\mathrm{F}(1,21)=0.5, p=.48)$ and no interaction between cycle phase and sampling time (F $(1,21)=0.0, p=.87)$. There were no significant correlations between dexamethasone levels and post dexamethasone cortisol levels or the magnitude of cortisol suppression from baseline at any time point.

\section{Lymphocyte Glucocorticoid Receptor mRNA Expression}

Estradiol and progesterone levels were lower in the follicular compared to the luteal phase of the menstrual cycle. Estradiol levels were $197 \pm 18$ vs. $580 \pm 44 \mathrm{pmol} /$ $\mathrm{L}(t=9.1, p<.0001)$ and progesterone levels were $1.6 \pm$ 0.1 vs. $43.8 \pm 3.8 \mathrm{nmol} / \mathrm{L}(t=11.2, p<.0001)$. Basal cortisol levels were similar in the follicular and luteal

\section{POST DEXAMETHASONE CORTISOL SUPPRESSION}

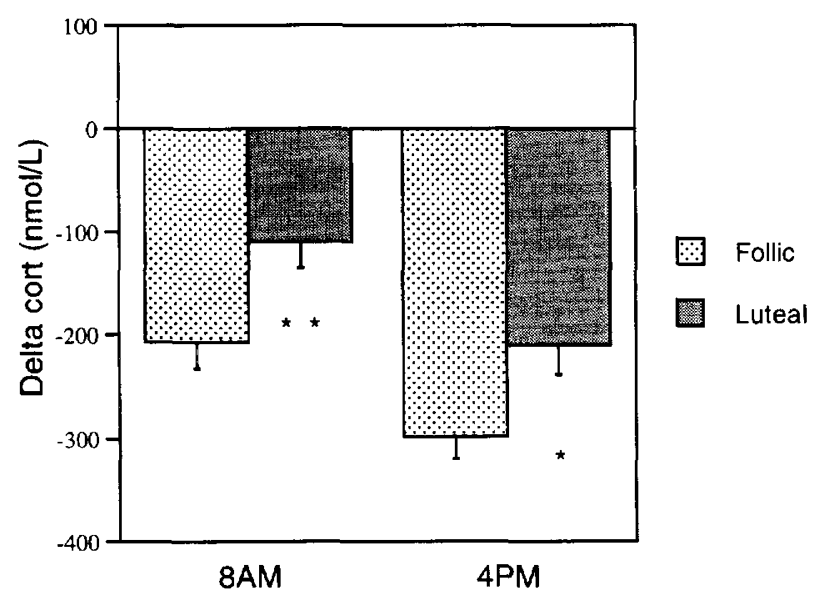

Figure 1. Change in plasma cortisol from 8 A.M. baseline at 8 A.M. and 4 P.M. following an 11 P.M. dose of 0.25 mg dexamethasone. Cortisol suppression was significantly greater in the follicular phase of the cycle at both 8 A.M. and 4 P.M. $\left({ }^{*} p<\right.$ $\left..05,{ }^{* *} p<.01\right)$. phases of the cycle $(410 \pm 27$ vs. $388 \pm 22 \mathrm{nmol} / \mathrm{L}, t=$ $0.9, p=.4)$.

Comparison of signal from the glucocorticoid receptor probe with values of molecular weight standards on the same gel showed that the human glucocorticoid receptor probe hybridized to an RNA species of approximately $7.1 \mathrm{~kg}$, similar to findings in several other human tissues (Hollenberg et al. 1985; Chomczynski and Sacchi 1987) (Figure 2). The ratio of glucocorticoid receptor mRNA to GAPDH mRNA signal was significantly increased in the follicular compared to the luteal phase of the cycle. Ratio values were $1.60 \pm 0.27$ in the follicular phase and $0.90 \pm 0.07$ in the luteal phase of the cycle $(t=2.6, p<.02)$ (Figure 3 ).

\section{DISCUSSION}

There was a greater suppression of plasma cortisol in response to a $0.25 \mathrm{mg}$ dose of dexamethasone in the follicular compared to the luteal phase of the menstrual cycle. In addition, expression of the type II glucocorticoid receptor gene in lymphocytes was increased in the follicular phase of the cycle. The results of these two studies are consistent and suggest that, in humans, the luteal phase of the menstrual cycle is associated with reduced sensitivity to glucocorticoid feedback. Enhanced cortisol suppression in response to dexamethasone during the early follicular phase was also noted in one study of depressed patients (Tandon et al. 1991). Two prior studies of dexamethasone suppression in non-depressed, healthy women did not find an effect of cycle phase, most likely because the standard $1.0 \mathrm{mg}$ dose of dexamethasone caused a complete or almost complete suppression of cortisol in both phases of the cycle (Parker et al. 1983; Roy-Byrne et al. 1986).

Although the majority of studies have found no effect of menstrual cycle phase on cortisol responses to a

Table 1. Effect of Menstrual Cycle Phase on Cortisol Response to Dexamethasone

\begin{tabular}{lcc}
\hline & Follicular & Luteal \\
\hline Estradiol (pmol/L) & $206 \pm 18$ & $576 \pm 44^{a}$ \\
Progesterone (nmol/L) & $1.6 \pm 0.0$ & $50.8 \pm 3.8^{a}$ \\
Basal cortisol (nmol/L) & $419 \pm 19$ & $381 \pm 25$ \\
Post dex cortisol 8 A.M. (nmol/L) & $215 \pm 22$ & $270 \pm 22^{b}$ \\
Post dex cortisol 4 P.M. (nmol/L) & $143 \pm 17$ & $171 \pm 19$ \\
Delta cortisol 8 A.M. (nmol/L) & $-207 \pm 25$ & $-110 \pm 25^{b}$ \\
Delta cortisol 4 P.M. (nmol/L) & $-298 \pm 22$ & $-210 \pm 28^{c}$ \\
Dexamethasone 8 A.M. (ng/ml) & $0.64 \pm 0.05$ & $0.61 \pm 0.05$ \\
Dexamethasone 4 P.M. (ng/ml) & $0.24 \pm 0.02$ & $0.21 \pm 0.03$ \\
\hline
\end{tabular}

${ }^{a} p<.001$.

${ }^{b} p<.01$.

i $p<.05$ follicular vs. luteal. 
variety of pharmacologic, physical and emotional stressors (Collins et al. 1985; Hoehe 1988; Bancroft et al. 1991; Kanaley et al. 1992), there have been three reports, consistent with the current study, of enhanced cortisol responses in the luteal phase and no reports of enhanced cortisol responses during the follicular phase of the cycle. In one study, cortisol responses to metoclopramide were enhanced in the luteal phase compared to the follicular phase (Seki 1989), and in the other, cortisol responses to a psychological stress were enhanced during the luteal phase compared to the ovulatory phase (Marinari et al. 1976). In the third study, the cortisol response to exercise was enhanced in the luteal phase (Lavoie et al. 1987). The findings in the current study are also consistent with a prior report in humans of reduced adrenocortical responses to stress during lactation, when, as in the follicular phase of the cycle, gonadal steroid levels are relatively suppressed (Altemus et al. 1995). Similarly, almost all studies of the effect of menstrual cycle phase on unstimulated plasma cortisol have found no changes across the menstrual cycle (Aubert et al. 1971; Schoneshofer and Wagner 1977; Parker et al. 1981; Rubinow et al. 1988; Caradente et al. 1990; Rabin et al. 1990; Heitkemper et al. 1991), but two studies did report higher cortisol levels in the luteal phase (Genazzani et al. 1975; Tersman et al. 1991), and no study has found higher cortisol levels in the follicular phase.

The findings in the current study are also compatible with a number of animal studies reporting estrogenassociated stimulation of HPA axis responsivity and estrogen-associated reductions in glucocorticoid receptor binding, gene transcription, and responsivity to agonists. (Peiffer and Barden 1987; Peiffer et al. 1991; Burgess and Handa 1992; Burgess and Handa 1993; Handa et al. 1994; Peiffer et al. 1994; Carey et al. 1995).

Although we noted a trend toward higher baseline cortisol levels in the follicular phase of the cycle in our dexamethasone suppression test samples, this was not likely to contribute to our finding of enhanced cortisol

\section{Follicular Luteal}

\section{$\begin{array}{llllll}1 & 2 & 3 & 1 & 2 & 3\end{array}$}

GR

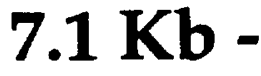

\section{GAPDH}

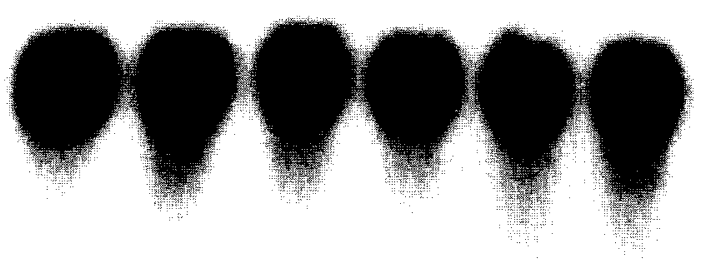

Figure 2. Representative Northern demonstrating type II glucocorticoid receptor mRNA expression in peripheral blood lymphocytes. Samples were collected from 3 subjects in the early follicular and midluteal phases of the menstrual cycle. 
suppression in the follicular phase because a number of studies have demonstrated that higher baseline cortisol levels are associated with reduced cortisol suppression in response to dexamethasone (Carroll et al. 1976; Amsterdam et al. 1982; Sapolsky et al. 1986; Rubin et al. 1987; Young et al. 1993; Yehuda et al. 1995).

Multiple studies of dexamethasone suppression of cortisol levels in psychiatric patient groups have shown that nonsuppression of cortisol is often associated with lower plasma dexamethasone levels (Morris et al. 1986; Maguire et al. 1987; Young et al. 1993). This was not a confounding factor in our study, since there was no difference in dexamethasone levels across the cycle at 8 A.M. or 4 P.M. and no correlation between dexamethasone levels and absolute post dexamethasone cortisol levels or the post-dexamethasone change in cortisol levels.

The physiological mechanisms through which hormonal changes across the menstrual cycle may modulate HPA axis activity remain to be clarified. Sensitivity to the negative feedback by dexamethasone may be reduced in luteal phase, or alternatively, activity of multiple systems which activate the HPA axis may be enhanced in the luteal phase of the cycle.

The finding of reductions in lymphocyte mRNA during the luteal phase suggests that changes in cortisol suppression in response to dexamethasone across the cycle are mediated, at least in part, by changes in the efficiency of dexamethasone feedback at glucocorticoid receptors. It should be noted, however, that we are not able to obtain human mRNA samples from brain or pituitary tissues which directly mediate glucocorticoid

\section{EFFECT OF CYCLE PHASE ON GR MRNA}

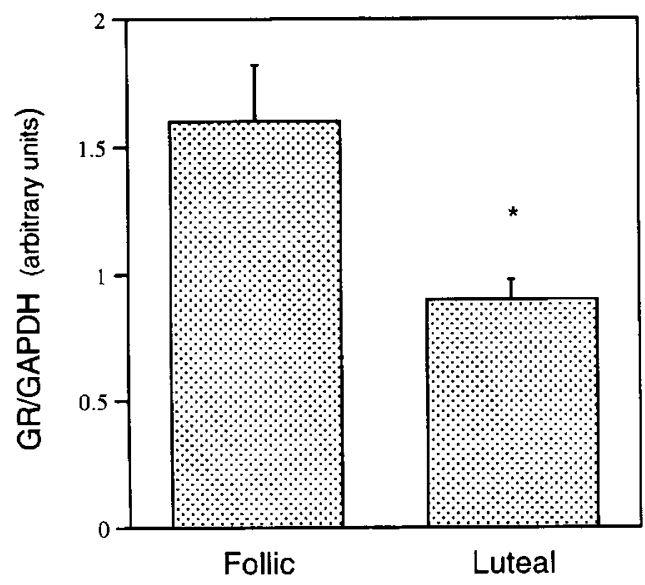

Figure 3. Type II glucocorticoid receptor mRNA expression in lymphocytes, expressed in arbitrary units of the glucocorticoid receptor (GR) $m R N A / G A P D H ~ m R N A$ ratio. The ratio of glucocorticoid receptor/GAPDH mRNA was significantly reduced in the luteal compared to the follicular phase of the cycle $\left({ }^{*} p<.02\right)$. feedback on the HPA axis. Studies in rats do indicate that estrogen reduces type II glucocorticoid receptor mRNA expression in parallel in multiple tissues, including the hippocampus (Burgess and Handa 1993), pituitary (Peiffer and Barden 1987), and thymus (Peiffer et al. 1994).

It should also be noted that enhanced sensitivity to dexamethasone at the pituitary during the follicular phase of the cycle could produce the dexamethasone suppression test findings reported here, independent of any brain changes which may occur with the cycle. In rats, pituitary glucocorticoid receptors are much more sensitive than hippocampal and hypothalamic receptors to activation by dexamethasone, due in part to poor penetration of the blood brain barrier by dexamethasone (DeKloet et al. 1975; Turner 1986; Spencer et al. 1990; Miller et al. 1992). On the other hand, hormonal changes within the menstrual cycle or during postmenopausal estrogen and progesterone replacement do not change the pituitary adrenocorticotropin response to corticotropin releasing hormone infusion (Liu et al. 1987; Rabin et al. 1990), which is sensitive to feedback by circulating glucocorticoids.

Estrogen most likely affects glucocorticoid receptor mRNA expression by activating estrogen receptors which have been identified in the paraventricular nucleus and hippocampus (Simerly et al. 1990; Bettini et al. 1993). A putative estrogen response site has been identified on the type II glucocorticoid receptor gene, but it has not yet been demonstrated to be functional (Detera-Wadleigh, unpublished data). An estrogen response element has also been identified on the corticotropin releasing hormone gene (Vamvakopoulos and Chrousos 1993), suggesting that direct estrogen modulation of corticotropin releasing hormone gene expression also may play a role in determining reduced suppression following lowdose dexamethasone administration in the luteal phase of the cycle, independent of changes in glucocorticoid receptor activity. Estrogen may also modulate glucocorticoid receptor gene expression and function by interacting with other transcriptional activation or repressor mechanisms (Green and Chambon 1987; Cato and Ponta 1989). It is also possible that estrogen and progesterone may modulate HPA axis function through non-genomic, non-receptor mediated mechanisms (Smith et al. 1987; Wong and Moss 1992; McEwen 1994).

In addition to direct modulation of the glucocorticoid receptor, corticotropin releasing hormone, or other components of the HPA axis, gonadal steroids may alter HPA axis responsivity by influencing the activity of a number of neurotransmitter systems which contribute to regulation of the HPA axis, including the serotonergic and noradrenergic systems (Szafarczyk et al. 1985; Mitchell et al. 1990; Feldman and Weidenfeld 1991; Maccari et al. 1992), as well as GABA and glutaminergic systems (Calogero et al. 1988). 
Animal studies indicate that estrogen can activate central noradrenergic systems (Petitti et al. 1992; Etgen and Karkanias 1994). Both estrogen and progesterone impair monoamine oxidase activity (Klaiber et al. 1971; Luine and Rhodes 1983) and estrogens also inhibit norepinephrine reuptake and activity of the degradative enzyme catechol-o-methyl transferase (Iverson 1973; Brener et al. 1978). In addition, estrogen appears to affect several aspects of central serotonin systems in rats including serotonin content, synthesis, uptake, and receptor binding (Biegon et al. 1983; Fishette et al. 1984; Rehavi et al. 1987; Cohen and Wise 1988; Frankfurt et al. 1994).

Progesterone metabolites seem to potentiate activation of GABA-A binding sites (Majewski 1992) and to enhancing adenosine function (Phillis 1986). Neither of these effects, however, are in a direction which would seem likely to contribute relative activation of the HPA axis in the luteal phase.

Estrogen and progesterone also have been shown to alter neuronal structure, including dendritic branching and synapse formation, it the arcuate nucleus of the hypothalamus, the striatum (Morissette et al. 1992) and the CA1 pyramidal neurons of the hippocampus (Woolley and McEwen 1992). Glucocorticoid receptors in hippocampal pyramidal cells, in particular, are known to play an important role in HPA axis feedback regulation (Herman et al. 1989b). In rats, changes in both dendritic branching and synapse formation in the hippocampus can be seen within the normal estrus cycle (Woolley and McEwen 1993).

A limitation of the naturalistic design of this study is that the relative contributions of changes in estrogen and progesterone to the changes in dexamethasone suppression and glucocorticoid receptor mRNA expression seen across the cycle cannot be determined. In addition, the time course and stability of these changes in glucocorticoid receptor feedback sensitivity remain to be described. It is possible that similar changes in glucocorticoid feedback sensitivity also occur during pregnancy and menopause when, as in the menstrual cycle, estrogen and progesterone levels change in parallel.

Finally, these changes in glucocorticoid receptor function across the menstrual cycle may contribute to the mood changes experienced by the majority of women premenstrually (Johnson 1987) by reducing glucocorticoid feedback restraint of central stress-response systems during the luteal phase. Several stress-responsive, arousal producing systems in the brain are suppressed by glucocorticoids, including noradrenergic activity in the locus coeruleus and hippocampus (Joels and DeKloet 1989), and central activity of the neuropeptides corticotropin releasing hormone, vasopressin and somatostatin (Wolkowitz et al. 1990; Kling et al. 1991; Kling et al. 1993). Peripheral sympathetic nervous system activity also seems to be suppressed by glucocorticoids (Brown and Fisher 1986). Enhanced activation of these central stress-response systems in the luteal phase of the menstrual cycle may contribute to the commonly reported premenstrual symptoms of irritability, anxiety, and dysphoria.

\section{REFERENCES}

Altemus M, Deuster P, Galliven E, Carter S, Gold PW (1995): Suppression of hypiothalamic-pituitary adrenal axis, responses to stress in lactating women. J Clin Endo Metab 80:2954-2959

Amsterdam JD, Winokur A, Caroff CN, Conn J (1982): The dexamethasone suppression test in outpatients with primary affective disorder and healthy control subjects. Am J Psychiatry 139:287-291

Aubert ML, Lemarchand-Beraud T, Degullaume R, Desaulles PA (1971): Cortisol secretion during the normal menstrual cycle. Acta Endocrinol (Copenhagen) 155:78

Bancroft J, Cook A, Davidson D, Bennie J, Goodwin G (1991): Blunting of neuroendocrine responses to infusion of 1-tryptophan in women with peri-menstrual mood change. Psychol Med 21:305-312

Bellingham DL, Sar M, Cidlowski JA (1992): Ligand-dependent down-regulation of stably transfected human glucocorticoid receptors is associated with the loss of functional glucocorticoid responsiveness. Mol Endocrinol 6:2090-2102

Bettini E, Pollio G, Santagati S, Maggi A (1993): Estrogen receptor in rat brain: presence in the hippocampal formation. Neuroendocrinology 56:502-508

Biegon A, Reches A, Snyder L, McEwen BS (1983): Serotonergic and noradrenergic receptors in the rat brain: Modulation by chronic exposures to ovarian hormones. Life Sciences 32:2015-2021

Bohler HCL, Zoeller T, King JC, Rubin BJ, Wever R, Merriam GR (1990): Corticotropin releasing hormone mRNA is elevated on the afternoon of proestrus in the parvocellular paraventricular nuclei of the female rat. Mol Brain Res 8:259-262

Bradbury MJ, Akana SF, Dallman MF (1994): Roles of type I and II corticosteroid receptors in regulation of basal activity in the hypothalamo-pituitary-adrenal axis during the diurnal trough and the peak: evidence for a nonadditive effect of combined receptor occupation. Endocrinology 134:1286-1296

Brener H, Koster G, Schneider ST, Ladowsky W (1978): Interactions between estrogens and neurotransmitters. Effects of estrogens on the enzymatic methylation of noradrenaline in the brain. In Scott DE, Roslowski GE, Weindl A (eds), Brain Endocrine Interactions. Basel, Karger, pp. 274-285

Brown M, Fisher L (1986): Glucocorticoid suppression of the sympathetic nervous system and adrenal medulla. Life Sci 39:1003-1012

Burgess LH, Handa RJ (1992): Chronic estrogen-induced alterations in adrenocorticotropin and corticosterone secretion, and glucocorticoid receptor-mediated functions in female rats. Endocrinology 131:1261-1269

Burgess LH, Handa RJ (1993): Estrogen-induced alterations 
in the regulation of mineralocorticoid and glucocorticoid receptor messenger RNA expression in the female rat anterior pituitary gland and brain. Molecular and Cellular Neuroscience 4:191-198

Calogero AE, Gallucci WT, Gold PW, Chrousos GP (1988): Multiple regulatory feedback loops on hypothalamic corticotropin releasing hormone secretion. J Clin Invest 82:767-774

Caradente F, Angeli A, Candiani GB, Crosignani PG, Dammacco F, DeCecco L, Marrama P, Massobrio M, Martini L (1990): Rhythms in the ovulatory cycle, III: cortisol and dehydroepiandrosterone sulfate (DHEA-S). Chronobiologia 17:209-217

Carey MP, Deterd CH, Koning JD, Helmerhorst F, Kloet ERD (1995): The influence of ovarian steroids on hypthalamic-pituitary-adrenal regulation in the female rat. J Endocrinology 144:311-321

Carroll BJ, Curtis GC, Mendels J (1976): Neuroendocrine regulation in depression, II: discrimination of depressed from nondepressed patients. Arch Gen Psychiatry 33: 1051-1058

Cato ACB, Ponta H (1989): Different regions of the estrogen receptor are required for synergistic action with the glucocorticoid and progesterone receptors. Mol Cell Biol 9:5324-5330

Chomczynski P, Sacchi N (1987): Single step method of RNA isolation by acid guanidium thiocyanate-phenol chloroform extraction. Anal Biochem 162:156-159

Chrousos GP, Gold PW (1992): The concepts of stress and stress system disorders. Overview of physical and behavioral homeostasis. JAMA 267:1244-1252

Cohen I, Wise P (1988): Effects of estradiol on the diurnal rhythm of serotonin activity in microdissected areas of ovariectomized rats. Endocrinology 122:2619-2625

Collins A, Eneroth P, Landgren B (1985): Psychoneuroendocrine stress responses and mood as related to the menstrual cycle. Psychosom Med 47:512-527

Crofford LJ, Pillemer SR, Kalogeras KT, Cash JM, Michelson D, King MA, Sternberg EM, Gold PW, Chrousos GP, Wilder RL (1994): Hypothalamic-pituitary-adrenal axis perturbations in patients with fibromyalgia. Arthritis Rheum 37:1583-1592

DeKloet E, Reul J (1987): Feedback action and tonic influence of corticosteroids on brain function: a concept arising from the heterogeneity of brain receptor systems. Psychoneuroendocrinology 12:83-105

DeKloet ER, Wallach G, McEwen BS (1975): Differences in corticosterone and dexamethasone binding to rat brain and pituitary. Endocrinology 95:598-609

DeLeon MJ, McRae T, Tsai JR, George AE, Marcus DL, Freedman M, Wolf AP, McEwen BS (1988): Abnormal cortisol response in Alzheimer's disease linked to hippocampal atrophy. Lancet ii:391-392

Denton RR, Eisen LP, Elsasser MS, Harmon JM (1993): Differential autoregulation of glucocorticoid receptor expression in human T- and B-cell lines. Endocrinology 133: 248-256

Dong Y, Poellinger L, Gustavsson J-A, Okret S (1988): Regulation of glucocorticoid receptor expression: evidence for transcriptional and posttranscriptional mechanisms. Mol Endocrinology 12:1256-1264
Etgen AM, Karkanias GB (1994): Estrogen regulation of noradrenergic signaling in the hypothalamus. Psychoneuroendocrinology 19:603-610

Feldman S, Weidenfeld J (1991): Depletion of hypothalamic norepinephrine and serotonin enhances the dexamethasone negative feedback effect on adrenocortical secretion. Psychoneuroendocrinology 16:397-405

Fischette CT, Biegon A, McEwen BS (1983): Sex differences in serotonin receptor binding in rat brain. Science 22:333-335

Fishette CT, Biegon A, McEwen BS (1984): Sex steroid modulation of the serotonin behavioral syndrome. Life Sci 35:1197-1206

Fort P, Marty L, Piechaczyk M, elSabrouty S, Dani C, Jeanteur P, Blanchard JM (1985): Various adult tissues express only one major mRNA species from the glyceraldehyde-3-phosphate-dehydrogenase multigenic family. Nucleic Acids Res 13:1431-1442

Frankfurt M, McKittrick CR, Mendelson SD, McEwen BS (1994): Effect of 5,7-dihydroxytryptamine, ovariectomey and gonadal steroids on serotonin receptor binding in rat brain. Neuroendocrinology 59:245-250

Genazzani AR, Lemarchand-Beraud TH, Auburt ML, Felber JP (1975): Patterns of plasma ACTH, hGH, and cortisol during the menstrual cycle. J Clin Endocrinol Metab 41:431-437

Giguere V, Hollenberg SM, Rosenfeld MG, Evans RM (1986): Functional domains of the human glucocorticoid receptor. Cell 46:645-652

Green S, Chambon P (1987): Oestradiol induction of a glucocorticoid-responsive gene by a chimeric receptor. Nature 325:75-78

Haas DA, George SR (1988): Gonadal regulation of corticotropin releasing factor immunoreactivity in hypothalamus. Brain Res Bull 20:361-367

Handa RJ, Nunley KM, Lorens SA, Louie JP, McGivern RF, Bollnow R (1994): Androgen regulation of adrenocorticotropin and corticosterone secretion in the male rat following novelty and foot shock stressors. Physiol Behav 55:117-124

Heitkemper M, Jarrett M, Bond EF, Turner P (1991): GI symptoms, function, and psychophysiological arousal in dysmenorrheic women. Nurs Res 40:20-26

Herman JP, Patel PD, Akil H, Watson SJ (1989a): Localization and regulation of glucocorticoid and mineralocorticoid receptor messenger RNAs in the hippocampal formation of the rat. Mol Endocrinol 3:1886-1894

Herman JP, Schafer MKH, Young EA, Thompson R, Douglass J, Akil H, Watson SJ (1989b): Evidence for hippocampal regulation of neuroendocrine neurons of the hypothalamo-pituitary-adrenocortical axis. J Neurosci 9:3072-3082

Hoehe M (1988): Influence of the menstrual cycle on neuroendocrine and behavioral responses to an opiate agonist in humans: preliminary results. Psychoneuroendocrinology 13:339-344

Hollenberg SM, Weinberger C, Ong ES, Cerelli G, Oro A, Lebo R, Thompson EB, Rosenfeld MG, Evans RM (1985): Primary structure and expression of a functional human glucocorticoid receptor cDNA. Nature 318:635-641 
Iverson LI (1973): Catecholamine uptake processes. Br Med Bull 29:130-135

Joels M, DeKloet ER (1989): Effects of glucocorticoid and norepinephrine on the excitability in the hippocampus. Science 245:1502-1505

Johnson SR (1987): The epidemiology and social impacts of premenstrual symptoms. Clin Obstet Gynecol 30:367-376

Kalinyak JE, Dorin RI, Hoffman AR, Perlman AJ (1987): Tissue-specific regulation of glucocorticoid receptor mRNA by dexamethasone. J Biol Chem 262:10441-10444

Kanaley JA, Boileau RA, Bahr JM, Misner JE, Nelson RA (1992): Cortisol levels during prolonged exercise: the influence of menstrual phase and menstrual status. Int J Sports Md 13:332-336

Kitay JI (1963): Pituitary-adrenal function in the rat after gonadectomey and gonadal replacement. Endocrinology 73:253-260

Klaiber EL, Kobayashi Y, Braverman DM, Hall F (1971): Plasma monoamineoxidase activity in regularly menstruating women and in amenorrheic women receiving cyclic treatment with estrogens and a progestin. J Clin Endocrinol Metab 33:630-638

Kling M, Roy A, Doran A, Calabrese J, Rubinow D, Whitfield C, May R, Post R, Gold P (1991): Cerebrospinal fluid immunoreactive corticotropin-releasing hormone and adrenocorticotropin secretion in Cushing's disease and major depression: Potential clinical implications. J Clin Endocrinol Metab 72:260-271

Kling M, Rubinow DR, Doran AR, Roy A, Davis DL, Calabrese J, Nieman LK, Post RM, Chrousos GP, Gold PW (1993): Cerebrospinal fluid immunoreactive somatostatin concentrations in patients with Cushing's disease and major depression: relationship to indices of corticotropin-releasing hormone and cortisol secretion. Neuroendocrinology 57:79-88

Knuttson U, Stierna P, Marcus C, Carlstedt-Duke J, Carlstrom K, Bronnegard M (1995): Effects of intranasal glucocorticoids on endogenous glucocorticoid peripheral and central function. J Endocrinology 144:301-310

Lavoie JM, Dionne N, Helie R, Brisson GR (1987): Menstrual cycle phase dissociation of blood glucose homeostasis during exercise. J Appl Physiol 62:1084-1089

Liu JH, Rasmussen DD, Ravier J, Vale W, Ten SSC (1987): Pituitary responses to synthetic corticotropin-releasing hormone: Absence of modulatory effects by estrogen and progestin. Am J Obstet Gynecol 157:1387-1391

Luine VN, Rhodes J (1983): Gonadal hormone regulation of $\mathrm{MAO}$ and other enzymes in hypothalamic areas. Neuroendocrinology 36:235-241

Maccari S, Mormede P, Piazza PV, Simon H, Angelucci L, LeMoal M (1992): Hippocampal type I and type II corticosteroid receptors are modulated by central noradrenergic systems. Psychoneuroendocrinolgy 17:103-112

Maguire KP, Schweitzer I, Biddle N, Bridge S, Tiller JWG (1987): The dexamethasone suppression test: importance of dexamethasone concentrations. Biol Psychiatry 22:957-967

Majewska MD (1992): Neurosteroids: endogenous bimodal modulators of the GABA-A receptor. Mechanism of action and physiological significance. Prog Neurobiol 38:379-395
Marinari KT, Leshner AI, Doyle MP (1976): Menstrual cycle status and adrenocortical reactivity to psychological stress. Psychoneuroendocrinology 1:213-218

McEwen BS (1994): Steroid hormone actions on the brain: When is the genome involved? Hormones and Behavior 28:396-405

Michelson D, Stone L, Galliven E, Magiakou MA, Chrousos GP, Sternberg EM, Gold PW (1994): Multiple sclerosis is associated with alterations in hypothalamic-pituitaryadrenal axis function. J Clin Endocrinol Metab 79:848-853

Miller AH, Spencer RL, Pulera M, Kang S, McEwen BS, Stein $M$ (1992): Adrenal steroid receptor activation in rat brain and pituitary following dexamethasone: Implications for the dexamethasone suppression test. Biol Psychiatry 32:850-869

Mitchell JB, Rowe W, Boksa P, Meaney MJ (1990): Serotonin regulates type II corticosteroid receptor binding in hippocampal cell cultures. J Neurosci 10:1745-1752

Morissette M, Garcia-Seguar LM, Belanger A, DiPaolo T (1992): Changes of rat striatal neuronal membrane morphology and steroid content during the estrous cycle. Neuroscience 49:893-902

Morris H, Carr V, Gilliland J, Hooper M (1986): Dexamethasone concentrations and the dexamethasone suppression test in psychiatric disorders. Br J Psychiatry 148:66-69

Parker CR, Rush M, MacDonald PC (1983): Serum concentrations of deoxycorticosterone in women during the luteal phase of the ovarian cycle are not suppressed by dexamethasone treatment. J Steroid Biochem 19:1313-1317

Parker CR, Winkel CA, Rush M, Porter JC, MacDonald PC (1981): Plasma concentrations of 11-deoxycorticosterone in women during the menstrual cycle. Obstet Gynecol $58: 26-30$

Peiffer A, Barden N (1987): Estrogen-induced decrease of glucocorticoid receptor messenger ribonucleic acid concentration in rat anterior pituitary gland. Mol Endocrinology 1:435-440

Peiffer A, LaPointe B, Barden N (1991): Hormonal regulation of type II glucocorticoid receptor messenger ribonucleic acid in rat brain. Endocrinology 129:2166-2174

Peiffer A, Morale MC, Barden N, Marchetti B (1994): Modulation of glucocorticoid receptor gene expression in the thymus by the sex steroid hormone milieu and correlation with sexual dimorphism of immune response. Endocrine J 2:181-192

Petitti N, Karkania GB, Etgen AM (1992): Estradiol selectively regulates a1B-noradrenergic receptors in the hypothalamus and preoptic area. J Neurosci 12:38693876

Phillis J (1986): Potentiation of the depression by adenosine of rat cerebral, cortical neurones by progestational agents. Br J Pharmacol 89:693-702

Pollard I, White B, Banett JR, Cairncross KD (1975): Plasma glucocorticoid elevation and desynchronization of the estrous cycle following unpredictable stress in the rat. Behav Biol 14:103-108

Rabin DS, Schmidt PJ, Campbell G, Gold PW, Jensvold M, Rubinow DR, Chrousos GP (1990): Hypothalamic-pituitary-adrenal function in patients with the premenstrual syndrome. J Clin Endocrinol Metab 71:1158-1162 
Rehavi M, Sepcut H, Weizman A (1987): Upregulation of imipramine binding and serotonin uptake by estradiol in female rat brain. Brain Res 410:135-139

Reul JMH, deKloet ER (1985): Two receptor systems for corticosterone in rat brain: microdistribution and differential occupation. Endocrinology 117:2505-2511

Rothuizen J, Reul JM, vanSluigs FJ, Mol JA, Rijnberk A, deKloet ER (1993): Increased neuroendocrine reactivity and decreased brain mineralocorticoid receptor-binding capacity in aged dogs. Endocrinology 132:161-168

Roy-Byrne PP, Rubinow DR, Gwirtsman H, Hoban C, Grover GN (1986): Cortisol response to dexamethasone in women with premenstrual syndrome. Neuropsychobiology 16:61-63

Rubin RT, Poland PE, Lesser IM, Winston RA, Blodgett N (1987): Neuroendocrine aspects of primary endogenous depression, I: cortisol secretory dynamics in patients and matched controls. Arch Gen Psychiatry 44:328-336

Rubinow DR, Hoban MC, Grover GN, Galloway DS, RoyByrne P, Andersen R, Merriam GR (1988): Changes in plasma hormones across the menstrual cycle in patients with menstrually related mood disorder and in control subjects. Am J Obstet Gynecol 158:5-11

Sapolsky R, Krey L, McEwen BS (1986): The neuroendocrinology of stress and aging: the glucocorticoid cascade hypothesis. Endocr Rev 7:284-301

Schlechte JA, Ginsberg BH, Sherman BM (1982): Regulation of the glucocorticoid receptor in human lymphocytes. J Steroid Biochem 16:69-74

Schoneshofer M, Wagner GG (1977): Sex differences in corticosteroids in man. J Clin Endocrinol Metab 45:814-817

Seki K (1989): Variability of cortisol and adrenocorticotropic hormone responses to metoclopramide during the menstrual cycle. Gynecol Obstet Invest 27:201-203

Simerly RB, Chang C, Muramatsu M, Swanson LW (1990): Distribution of androgen and estrogen receptor mRNA containing cells in the rat brain. J Comp Neurol 294:76-95

Smith SS, Waterhouse BD, Woodward DJ (1987): I. Estrogen augments neuronal responsiveness to iontophoretically applied glutamate in the cerebrellum. Brain Res 422:40-51

Spencer RL, Miller AH, Moday H, Stein M, McEwen BS (1993): Diurnal differences in basal and acute stress levels of type I and type II adrenal steroid receptor activation in neural and immune tissues. Endocrinology 133:1941-1950

Spencer RL, Young EA, Choo PH, McEwen BS (1990: Adrenal steroid type I and type II receptor binding: estimates of in vivo receptor number, occupancy, and activation with varying level of steroid. Brain Res 514:37-48

Spitzer RL, Williams JBW, Gibbon M, First MB (1990): Structured Clinical Interview for DSM-III-R (SCID, version 1.0). Washington, DC, American Psychiatric Press

Swanson L, Simmons D (1989): Differential steroid hormone and neural influences on peptide mRNA levels in $\mathrm{CRH}$ cells of the paraventricular nucleus: A hybridization histochemical study in the rat. J Comp Neurol 285:413-435

Szafarczyk A, Alonso G, Ixart G, Malavol F, Assenmacher I (1985): Diurnal-stimulated and stress-induced ACTH release in rats is mediated by ventral noradrenergic bundle. Am J Physiol 249:E219-E226

Tandon R, Haskett RF, Cardona D, Alcser K, Greden JF (1991): Menstrual cycle effects on the dexamethasone suppression test in major depression. Biol Psychiatry 29:485-488

Tersman Z, Collins A, Eneroth P (1991): Cardiovascular responses to psychological and physiological stressors during the menstrual cycle. Psychosom Med 53:185-197

Turner BB (1986): Tissue differences in the up-regulation of glucocorticoid-binding proteins in the rat. Endocrinology 118:1211-1216

Turner BB, Weaver DA (1985): Sexual dimorphism of glucocorticoid binding in rat brain. Brain Res 343:16-23

Vamvakopoulos NC, Chrousos GP (1993): Structural organization for the $5^{\prime}$ flanking region of the human corticotropin releasing hormone gene. DNA Seq 4:197-206

Viau V, Meaney MJ (1991): Variations in the hypothalamicpituitary-adrenal response to stress during the estrous cycle in the rat. Endocrinology 129:2503-2511

Wolkowitz OM, Rubinow DR, Doran AR, Brier A, Berrettini WH, Kling MA, Pickar D (1990): Prednisone effects on neurochemistry and behavior. Arch Gen Psychiatry 47: 963-968

Wong M, Moss RL (1992): Long-term and short-term electrophysiological effects of estrogen on the synaptic properties of hippocampal CA1 neurons. J Neurosci 12: 32173225

Woolley C, McEwen BS (1992): Estradiol mediates fluctuation in hippocampal synapse density during the estrous cycle in the adult rat. J Neurosci 12:2549-2554

Woolley C, McEwen BS (1993): Roles of estradiol and progesterone in regulation of hippocampal dendritic spine density during the estrous cycle in the rat. J Comp Neurol 336:293-306

Yehuda R, Boisoneau D, Lowy MT, Giller EL (1995): Doseresponse changes in plasma cortisol and lymphocyte glucocorticoid receptors following dexamethasone administration in combat veterans with and without posttraumatic stress disorder. Arch Gen Psychiatry 52:583-593

Yehuda R, Southwick SM, Krystal JH, Charney DS, Mason JW (1993): Enhanced suppression of cortisol following a low dose of dexamethasone in combat veterans with posttraumatic stress disorder. Am J Psychiatry 150:83-96

Young EA, Kotun J, Haskett RF, Grunhaus L, Greden JF, Watson SJ, Akil H (1993): Dissociation between pituitary and adrenal suppression to dexamethasone in depression. Arch Gen Psychiatry 50:395-403 